\title{
KEPEMIMPINAN PEREMPUAN DALAM PERSPEKTIF ISLAM
}

\author{
Dhurotun Nasicha Aliyatul Himmah ${ }^{1}$, Nurul Yaqien ${ }^{2}$ \\ Email: argirlzdnasich@yahoo.com ${ }^{1}$, nyaqien@mpi.uin-malang.ac.id ${ }^{2}$ \\ Universitas Islam Negeri Maulana Malik Ibrahim Malang
}

\begin{abstract}
Women's leadership has always been a discussion of controversy, especially in explaining, interpreting and determining the law of a woman's leadership. This study aims to: (1) Review the interpretation related to the concept of leadership with the interpretation model of maudhu'i Al-Qur'an letter An-Nisa verse 34 and Al-Mujadalah verse 11 according to some classical and contemporary commentators including Ibn Abbas, Imam Jalaludin, Ibn Kathir, Mustafa Al-Maraghi, Muhammad Hasbi and Quraish Shihab, (2) Assessing the relevance of the concept of female leadership in an Islamic perspective with the concept of leadership in the 21st century. This type of research is literature study using descriptive-analytic method, historical-philosophical approach, carried out with documentation techniques, analysis, interpretation, checking the validity of the data to obtain the results of the study according to purpose. The results of the study show that there are differences between the thoughts of classical mufassir and contemporary mufassir on women's leadership based on An-Nisa verse 34. It is the differences in times, conditions, situations and civilizations that influence it. The 21st Century is no longer a century where women cannot join in politics, government, social affairs, education, and so on. Contemporary mufassir allow women to be leaders as long as they do not violate the sharia and do not ignore the main task of being a wife. Relevance is related to the realization of the Constitution of 1945 article 27 concerning equal rights and obligations of Indonesian citizens, and Article 31 related to the right of education for all citizens of Indonesia relevant to the letter of Al-Mujadalah verse 11. The relevance is related to the realization of Article 27 of the 1945 constitution concerning the equality of Indonesian citizens' rights and obligations, and Article 31 concerning the right of education of all Indonesian citizens relevant to Al-Mujadalah verse 11. Men or women who are leaders, most importantly is the realization of the good leadership for creating baldatun thayyibun warabbun ghafur.
\end{abstract}

Keywords: Women's Leadership, Islam, Maudhu'i Interpretation

\section{Abstrak}

Kepemimpinan perempuan selalu menjadi perbincangan kontroversi, terlebih dalam menjelaskan, menafsirkan dan menentukan hukum dari kepemimpinan seorang perempuan. Penelitian ini bertujuan untuk: (1) Mengkaji penafsiran terkait konsep kepemimpinan dengan model tafsir maudhu'i Al-Qur'an surat An-Nisa' ayat 34 dan AlMujadalah ayat 11 menurut beberapa mufassir klasik dan kontemporer diantaranya Ibnu Abbas, Imam Jalaludin, Ibnu Katsir, Musthafa Al-Maraghi, Muhammad Hasbi dan Quraish Shihab, (2) Mengkaji relevansi antara konsep kepemimpinan perempuan dalam perspektif Islam dengan konsep kepemimpinan di abad-21 ini. Jenis penelitian ini adalah studi kepustakaan menggunakan metode deskriptif-analitik, pendekatan historis-filosofis, dilakukan dengan teknik dokumentasi, analisis, interpretasi, dan pengecekan keabsahan data untuk mendapatkan hasil penelitian sesuai tujuan. Hasil penelitian menunjukkan bahwa terdapat perbedaan antara pemikiran para mufassir klasik dengan mufassir kontemporer terkait kepemimpinan perempuan yang berlandaskan surat An-Nisa' ayat 34. Perbedaan zaman, kondisi, situasi serta peradabanlah yang mempengaruhinya. Abad-21 bukanlah lagi abad dimana perempuan tidak bisa bergelut di kancah politik, pemerintahan, sosial, pendidikan, dan 
lain-lain. Mufassir kontemporer memperbolehkan perempuan menjadi pemimpin asalkan tidak melanggar syari'at dan tidak mengabaikan tugas utama menjadi istri. Relevansinya dikaitkan dengan realisasi Undang-undang Dasar 1945 pasal 27 terkait persamaan hak dan kewajiban warga Indonesia, dan pasal 31 terkait hak pendidikan bagi seluruh warga Indonesia yang relevan dengan surat Al-Mujadalah ayat 11. Lakilaki atau perempuan yang menjadi pemimpin, yang terpenting adalah terwujudnya kepemimpinan maslahah, menciptakan baldatun thayyibun warabbun ghafur.

Kata kunci: Kepemimpinan Perempuan, Islam, Tafsir Maudhu'i

\section{Pendahuluan}

Wacana hukum Islam di Indonesia tentang boleh atau tidaknya perempuan menduduki jabatan publik, baik itu mikro ataupun makro, mempunyai hal baru dalam pembahasannya, yakni dengan mempertimbangkan berbagai bentuk fakta yang telah terjadi. Topik ini mulai muncul sejak era reformasi, sejak lengsernya Gus Dur dari jabatan Presiden, yang kemudian digantikan secara resmi oleh wakilnya, yakni ibu Megawati Soekarno Putri. Indonesia mulai menjajaki suasana baru pada saat era reformasi tersebut, yakni dengan memiliki seorang pemimpin berjenis kelamin perempuan (Ibad, 2011).

Pasal 27 ayat 1 Undang-Undang Dasar 1945 menyatakan bahwa semua warga negara bersamaan kedudukannya di dalam hukum dan pemerintahan dan wajib menjunjung hukum dan pemerintahan itu dengan tidak ada kecualinya. Pada pasal 28 D ayat 3 juga ditegaskan bahwa setiap warga negara berhak memperoleh kesempatan yang sama dalam pemerintahan. Hak seorang warga Negara Indonesia bila dikaitkan dengan Undangundang tersebut dalam perihal menjadi seorang pemimpin yakni, bahwa setiap warga negara Indonesia sepanjang memenuhi persyaratan sesuai dengan ketentuan peraturan perundang-undangan berhak menjadi pemimpin, yang tak terkecuali dalam hal ini termasuk kaum perempuan.

Dunia mengakui bahwa laki-laki digariskan mempunyai derajat lebih dari seorang perempuan, baik dalam banyak hal. Perbedaan yang menonjol antar keduanya juga signifikan baik secara fisik maupun psikologis. Sedangkan dalam hal ibadah, hak hidup, hak bersosialisasi, hak untuk menyuarakan pemikiran, pendapat, dan beberapa hal tertentu lainnya antara lelaki dan perempuan tidak ada perbedaan dari segi ketentuannya. Bermula dari titik tersebutlah, mulai adanya berbagai pemikiran baru tentang hukum serta kaidah kepemimpinan seorang perempuan, tentunya dengan tetap mempertahankan syariat Islam yang mencoba lebih fleksibel dalam kerelatifan abad 21 saat ini.

Penelitian ini bertujuan untuk: (1) Mengkaji penafsiran terkait konsep kepemimpinan dengan model tafsir maudhu'i Al-Qur'an surat An-Nisa' ayat 34 dan Al-Mujadalah ayat 11 menurut beberapa mufassir klasik dan kontemporer diantaranya Ibnu Abbas, Imam Jalaludin, Ibnu Katsir, Musthafa Al-Maraghi, Muhammad Hasbi dan Quraish Shihab, (2) Mengkaji relevansi antara konsep kepemimpinan perempuan dalam perspektif Islam dengan konsep kepemimpinan di abad-21 ini.

\section{Kajian Pustaka}

\section{Konsep Kepemimpinan}

Kepemimpinan menurut Fahim Tharaba merupakan bagian terpenting dari manajemen, tetap tidak sama dengan manajemen. Kepemimpinan merupakan kemampuan yang dipunyai seseorang untuk mempengaruhi orang lain agar bekerja mencapai tujuan dan sasaran yang telah ditentukan dalam suatu perumusan organisasi. Manajemen sendiri mencakup kepemimpinan, dan juga hal-hal lain seperti perencanaan, pengorganisasian, pengawasan serta evaluasi (Fahim Tharaba, 2016). Sedangkan definisi kepemimpinan menurut Soerjono Soekanto (2006) adalah kemampuan seseorang pemimpin atau leader untuk mempengaruhi orang lain (orang yang 
dipimpin atau para pengikut), sehingga orang lain tersebut bertingkah laku sesuai dengan apa yang dikehendaki oleh pemimpin.

\section{Konsep Perempuan}

Berbicara tentang perempuan, tentunya kita tidak akan bisa melepaskan diri dari pasangan jenisnya yakni laki-laki. Beberapa konsep yang mengatur hubungaan antara dua jenis kelamin ini salah satunya adalah teori nature dan teori nurture. Teori nature yang menyatakan bahwa secara biologis perempuan dan lakilaki memiliki perbedaan sejak lahir, dimana perbedaan ini merupakan kodrat dan tidak dapat ditukarkan satu sama lain, misalnya perempuan yang datang bulan, maka tidak wajar jika ditukarkan kepada laki-laki. Teori nurture yang menyatakan bahwa perbedaan peran dalam masyarakat antara kedua jenis kelamin ini disebabkan oleh perbedaan biologis, dan juga dari kultural masyarakat yang lebih menyatakan bahwa laki-laki lebih pantas sederajat lebih tinggi dari perempuan dalam sebuah roda kehidupan (Fitriyani, 2014).

\section{Konsep Kepemimpinan Perempuan Dalam Islam}

Islam mengizinkan perempuan menangani pertanian, perindustrian dan perdagangan, serta mengakad-akad perjanjian. Perempuan memegang segala macam hak milik, baginya boleh mengembangkan hartanya dan mengatur secara langsung segala urusan kehidupannya. Islam juga memperbolehkan diangkatnya seorang perempuan sebagai pejabat dalam pemerintahan, juga diperbolehkan bagi perempuan menangani pengadilan, memilih hakim, menunjuk seseorang untuk suatu tugas pemerintahan, mengemukakan pendapat yang bersifat politik, ekonomi, perundang-undangan, dan lain-lain sebagaimana boleh baginya mewakilkan dirinya kepada orang lain yang ia kehendaki untuk mengajukan gagasannya atau ia tampil sebagai wakil dari orang lain yang menghendakinya untuk mengajukan gagasan serupa, serta boleh baginya untuk melakukan berbagai hubungan yang mendatangkan kemashlahatan bersama (Said Al Afghani, 2001).

\section{Metode Penelitian}

Jenis penelitian yang digunakan adalah penelitian kepustakaan (library research), dengan metode deskriptifanalitik, menggunakan pendekatan historis-filosofis. Teknik yang digunakan yakni melalui tahap dokumentasi- AnalisisInterpretasi- Pengecekan keabsahan data (kredibilitas)- hingga menemukan hasil penelitian yang dimaksud.

\section{Hasil dan Pembahasan}

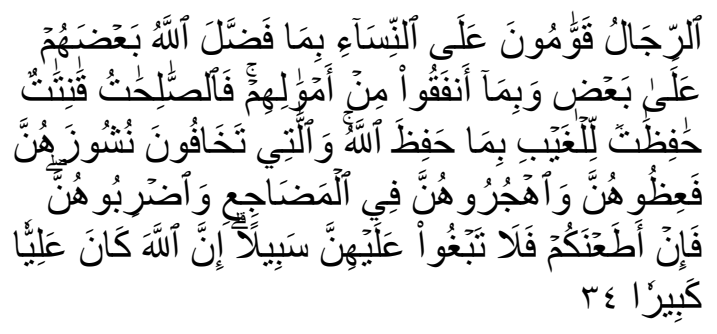

Artinya: "Kaum laki-laki itu adalah pemimpin bagi kaum wanita, oleh karena Allah telah melebihkan sebahagian mereka (laki-laki) atas sebahagian yang lain (wanita), dan karena mereka (laki-laki) telah menafkahkan sebagian dari harta mereka. Sebab itu maka wanita yang saleh, ialah yang taat kepada Allah lagi memelihara diri ketika suaminya tidak ada, oleh karena Allah telah memelihara (mereka). Wanita-wanita yang kamu khawatirkan nusyuznya, maka nasehatilah mereka dan pisahkanlah mereka di tempat tidur mereka, dan pukullah mereka. Kemudian jika mereka mentaatimu, maka janganlah kamu mencari-cari jalan untuk menyusahkannya. Sesungguhnya Allah Maha Tinggi lagi Maha Besar" (Al-Qur'an Surat An-Nisa': 34).

Menurut mufassir Ibnu Abbas dalam Muhammad bin Yaqub (817 H), kata qawwam yang selalu menjadi titik tolak ukur oleh para penolak hukum kepemimpinan perempuan, bermakna "musallithuuna 'ala adabi an-nisa"' yang bermakna "Menguasai atas perangai atau akhlaknya seorang perempuan", bukan menguasai atas segala kehidupan seorang perempuan tersebut. Kekuasaan tersebut diberlakukan dalam sebuah rumah tangga, yang mana suami menjadi surga atau nerakanya seorang perempuan. Segala 
perbuatan dan akhlak istri menjadi tanggung jawab suami terhadap Allah SWT.

Para mufassir klasik memberikan penafsiran atas surat an-Nisa' ayat 34 tersebut memanglah melihat konteks zaman yang sedang mereka jalani pada saat itu. Ulama seperti Ibnu Katsir, Al-Qurthubi, Ath-Thabari, Musthafa Al-Maraghi, dan Muhammad Hasbi dalam menafsirkan ayat tersebut benar-benar menyesuaikan zamannya, dimana masih sangat minim perempuan yang bergelut dalam perihal kepemimpinan, dan menerangkan dengan sangat jelas bahwasanya dalam masalah kepemimpinan keluarga, laki-laki lah pemimpinnya.

Quraish Shihab, Nasaruddin Umar, Husein Muhammad, Asghar Ali, dan beberapa Ulama kontemporer lainnya memberikan penafsiran lebih luas lagi terhadap ayat tersebut, yang mana lebih menitikberatkan pada konteks zaman serta kondisi yang ada. Apabila didapati perempuan lebih mumpuni serta kondisi mendesaknya untuk berkiprah menjadi seorang pemimpin baik itu ranah publik maupun domestik, maka itu bukanlah sebuah pelanggaran baik dari segi agama maupun kaidah negara.

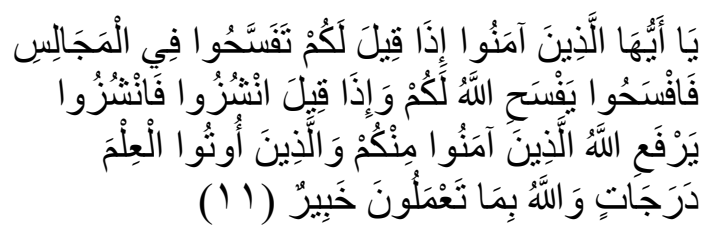

Artinya: "Hai orang-orang beriman apabila dikatakan kepadamu: "Berlapanglapanglah dalam majlis", maka lapangkanlah niscaya Allah akan memberi kelapangan untukmu. Dan apabila dikatakan: "Berdirilah kamu", maka berdirilah, niscaya Allah akan meninggikan orang-orang yang beriman di antaramu dan orang-orang yang diberi ilmu pengetahuan beberapa derajat. Dan Allah Maha Mengetahui apa yang kamu kerjakan"(Q.S. Al Mujadilah: 11)

Penjelasan dalam tafsir Ibnu Abbas tersebut, dengan sangat tegas mengunggulkan derajat orang yang berilmu. Hingga sampai ada perbandingan derajat bagi kaum mukmin yang berilmu dengan yang tidak berilmu. Allah SWT benar-benar memuliakan serta meninggikan kedudukan orang yang beriman yang disertai ilmu dalam imannya. Orang yang berilmu saja tidak cukup jika tidak disertai dengan iman kepada Allah SWT dan Rasul-Nya, karena perihal ilmu itu sendiri membutuhkan pemahaman dalam pendekatan manusia kepada Rabb-nya, sehingga dalam segala aturan dan poros kehidupannya, akan selalu mendapat rahmat Allah SWT.Begitu pula dengan orang yang beriman, tidak cukup hanya dengan memiliki iman saja tanpa ilmu, karena hal tersebut akan menyesatkannya.

Quraish Shihab (2007) dalam kitab tafsir Al-Misbahnya menjelaskan, kata

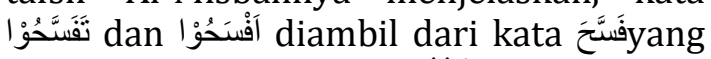

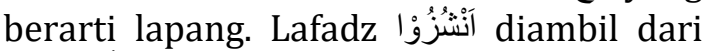

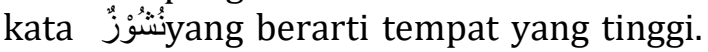
Perintah tersebut pada mulanya berarti "beralih ke tempat yang tinggi", yang dimaksud disini adalah pindah ke tempat lain untuk memberikan kesempatan kepada yang lebih wajar duduk atau berada di tempat yang wajar pindah itu, atau bangkit melakukan suatu aktivitas positif.

Hal tersebut dapat diluaskan pada penempatan perempuan sebagai pemimpin itu dianjurkan selama perempuan tersebut lebih wajar, lebih berhak, dan lebih mumpuni untuk memimpin dalam beberapa syarat menjadi pemimpin, dari pada laki-laki. Surat alMujadalah ayat 11 tersebut menegaskan, bahwa mereka yang memiliki derajat yakni yang lebih tinggi dari yang sekedar beriman. Ilmu yang dimiliki seorang manusia itulah yang berperan besar dalam ketinggian derajat yang diperolehnya dihadapan Allah SWT juga dihadapan manusia, bukan akibat dari faktor di luar ilmu itu (M. Quraisy Shihab, 2007).

Misi mengantarkan kejayaan suatu masyarakat, bangsa, dan bernegara oleh seorang pemimpin tersebut tidaklah hanya bisa dibatasi aturan yang hanya memprioritaskan pemimpin laki-laki saja, melainkan perempuan juga pastilah mampu melaksanakan amanah besar tersebut, selama masih dalam koridor syari'at yang diperbolehkan. Mengantarkan manusia ke dalam dimensi sosial bernegara yang Baldatun Thoyyibun 
wa Robbun Ghofur inilah yang harusnya menjadi idealisme setiap warga negara dan generasi muda di Indonesia ini, demi kejayaan bangsa di masa mendatang.

\section{Kesimpulan}

Kesimpulan dari penelitian ini adalah bahwa para mufassir klasik dan kontemporer memanglah hidup di zaman yang berbeda, dengan acuan hukum yang sama, yakni Al-Qur'an dan hadits. Oleh karenanya, wajar jika banyak terdapat perbedaan penafsiran dan pendapat terkait hukum kepemimpinan perempuan. Ulama seperti Imam Jalaludin, Ibnu Katsir, AlQurthubi, Ath-Thabari, Musthafa AlMaraghi, dan Muhammad Hasbi dalam menafsirkan surat an-Nisa' ayat 34, benarbenar menyesuaikan zamannya, dimana masih sangat minim perempuan yang bergelut dalam perihal kepemimpinan, dan menerangkan dengan sangat jelas bahwasanya dalam masalah kepemimpinan keluarga, laki-laki lah pemimpinnya. Quraish Shihab, Asghar Ali, dan beberapa ulama kontemporer lainya memberikan penafsiran lebih luas lagi terhadap surat an-Nisa' ayat 34 yang mana lebih menitikberatkan pada konteks zaman serta kondisi yang ada. Apabila didapati perempuan lebih mumpuni serta kondisi mendesaknya untuk berkiprah menjadi seorang pemimpin baik itu ranah publik maupun domestik, maka itu bukanlah sebuah pelanggaran baik dari segi agama maupun kaidah negara.

Allah SWT akan mengangkat derajat orang beriman yang berilmu, terutama yang menjadi pemimpin harus memiliki iman dan ilmu (Surat AlMujadalah ayat 11). Tanpa salah satu dari hal tersebut, maka akan menjadikan pemimpin tersebut bagaikan berjalan dengan satu kaki. Terkait permasalahan laki-laki atau perempuan yang menjadi pemimpin, Allah SWT tidak pernah membedakan keduanya, tentang siapa yang layak untuk menjadi pemimpin, yang terpenting adalah apakah pemimpin tersebut beriman dan berilmu atau tidaknya, karena syarat tersebut merupakan syarat mendasar yang wajib dimiliki oleh setiap pemimpin.

Jumlah perempuan di era Globalisasi dan Modernisasi pada abad 21 ini memanglah semakin meningkat secara pesat, oleh karenanya sangatlah dibutuhkan kontribusi perempuan dalam segala perubahan dan perkembangan zaman yang ada. Jika hanya laki-laki yang menangani semuanya, maka itu tidak akan cukup untuk mengatasi serta mengendalikan kepelikan perkembangan zaman ini. Potensi perempuan yang mumpuni dalam berbagai bidang patut untuk direalisasikan dan diberi posisi sehingga karunia dari Allah SWT terhadap perempuan tersebut tidak terabaikan secara sia-sia, posisi ini diberikan kepada perempuan dengan tanpa menghilangkan kodrat serta kewajibannya sebagai istri dan ibu bagi keluarganya. Termasuk di dalamnya merealisasikan UU No. 12 Tahun 2003 tentang Pemilu, pasal 65 ayat 1 tentang aturan calon legislatif yang telah memberikan kuota 30\% kursi bagi perempuan untuk bergelut di bidang pemeritahan di Indonesia.

Saran yang dapat penulis sampaikan terkait wacana kepemimpinan perempuan dalam perspektif Islam kajian tafsir Maudhu'i Al-Qur'an surat AnNisa'ayat 34 dan surat Al-Mujadalah ayat 11 ini adalah, agar kegiatan penelitian terkait kajian perempuan harus tetap dilaksanakan, dilihat dari pentingnya kajian tersebut bagi perkembangan dan peradaban zaman abad 21 ini. Melihat bahwa peradaban perempuan telah menyentuh berbagai segi kehidupan, yang tidak bisa lagi dibedakan antara kodrat ataupun derajat antara laki-laki dan perempuan. Hak antara laki-laki dan perempuan itu sama di mata negara, derajatnya pun sama di hadapan Allah SWT, hanya tingkat ketaqwaan yang membedakannya. Demi mencapai kesejahteraan bersama dalam berkehidupan, baiklah kiranya kita tetap mengembangkan ranah keilmuan di bidang kajian kepemimpinan perempuan ini, tentunya dengan tanpa mengabaikan posisi laki-laki dalam berkehidupan. 


\section{Daftar Pustaka}

Al-Qur'anul Karim. Mushaf Al-Firdaus: Terjemah dan Penjelasan Tematik Ayat. Tangerang: Penerbit AlFadhilah. 2002.

Fitriyani. Kepemimpinan Perempuan Dalam Islam: Studi Pemikiran M. Quraish Shihab. Skripsi, Fakultas Falsafah dan Peradaban Universitas Paramadina Jakarta. 2014.

Tharaba, Fahim. 2016. Kepemimpinan Pendidikan Islam. Malang: CV. Dream Litera Buana.

Muhammad Bin Ya'qub. 817H. Tanwirul Miqbas min Tafsir Ibnu Abbas. Dar Al-Hayat wa Kutubul Arabiyah Indonesia.

M. Quraish Shihab. 2007. Tafsir Al-Misbah: Pesan, Kesan dan Keserasian AlQur'an. Jakarta: Lentera Hati.

M. N Ibad. 2011. Kekuatan Perempuan dalam Perjuangan Gus Dur - Gus Miek. Yogyakarta: Pustaka Pesantren.

Said Al Afghani. 2001. Pemimpin Wanita Di Kancah Politik: Studi Sejarah Pemerintahab 'Aisyah. Yogyakarta: Putaka LP2IF.

Soekanto, Soerjono. 2006. Sosiologi Suatu Pengantar. Jakarta: Raja Grapindo Persada. 